\title{
A TRIBUTE RECORDANDO A RUDOLFO A. ANAYA: FROM AZTLÁN TO MICTLÁN
}

\author{
Francisco A. Lomelí \\ University of California Santa Barbara (USA)
}

El llano is mourning the passing of Rudolfo A. Anaya (Oct 30 1937-June 28 2020) where time became suspended, the wind stopped, and the juniper trees sighed. His death marks a watershed moment in many ways: the Quinto Sol Generation just got smaller; his legacy is forever an indelible memory; and his fame transcends his patria chica. He was a child from the dry eastern part of New Mexico where hardy people live and eke out a living, surrounded by an intensely ingrained tradition of Hispanos who go way back to the XVI century. He always felt grounded in his gente and his long-standing Nuevomexicano culture. That solid foundation rendered him a particular lens of confidence and identity as someone who shared a common history. This is why his works did not dwell on formulating a new ethnos since he knew perfectly well where he came from. As such, the Chicano social and literary movements benefited from his perspective because his characters were not interlopers nor phantoms. Quite the contrary, they seemed of flesh-and-blood or what some consider an embodiment of un Nuevo México profundo.

Such lived experiences helped shape Anaya into a keen observer of the human condition filled with life stories from an earthy world view. He was fundamentally grounded in oral storytelling while transmitting a rich mix of folklore of Hispano and indigenous tales, legends and myths. This was the fertile ground of an infinite imagination upon which to situate his characters in search of harmony, much the way the protagonist Antonio Márez recounted in a semi-autobiographical comingof-age novel known world-wide, the unforgettable Bless Me, Ultima. Antonio represented the synthesis of two peoples and two generations, their religious and cultural beliefs and social practices. The llano culture was the fountain that gave birth to his unique sensibilities: a deep appreciation for this rural culture that never left him. He instinctively returned to relive the quest to relish, explore and understand the New Mexican conscience because it nurtured his sense of place and purpose. In fact, most of his fiction, poetry, essays and plays are an extension of such a quest, a desdoblamiento of his inner questions and doubts about life, tragedy, death, a sense of resolution, spirituality and a deep awareness of humanity.

Of course, his long list of literary works in multiple genres denote a prolific writer of unmatched talents. He tended to produce distinctive groupings: the first as a trilogy about place and myth in his classic Bless Me, Ultima (1972), Heart of Aztlán (1976) and Tortuga (1979); a second one as a pre-Columbian exploration

DOI: https://doi.org/10.25145/j.recaesin.2020.81.18

Revista Canaria de Estudios IngLeSES, 81; November 2020, pp. 265-268; ISSN: e-2530-8335 
into the Chicano indigenous background in The Legend of La Llorona (1985), The Lord of the Dawn: Legend of Quetzalcóatl (1987), and to some degree Jalamanta: A Message from the Desert (1996); later a predilection for the detective fiction in Alburquerque (1992); followed by a series of mystery novels based on the four seasons such as Zia Summer (1995), Río Grande Fall (1996), Shaman Winter (1999) and Jemez Spring (2005); and folkloric renditions combined with sciencefiction in Curse of the Chupacabra (2006), Chupacabra and Roswell UFO (2008) and Chupacabra Meets Billy the Kid (2018). He also made an impact in children's literature with his acclaimed The Farolitos of Christmas; A New Mexico Christmas Story (1987), Roadrunner's Dance (2000) and The First Tortilla (2007). In addition, he effectively explored philosophical topics on love and death, for example, in The Old Man's Love Story (2013). He has also exceled in writing plays, poetry, essays and chronicles (i.e A Chicano in China [1986] or what Patricia Geuder calls "a chronicle of oneiric dimensions"). Y muchas más.

Such vast production has been extremely well received, although not unanimously as when certain school districts voted to burn Bless Me, Ultima for its supposed propagation of witchcraft and sorcery. Others questioned the mythic qualities as fanciful or anti-historical constructions, but he always tried to keep his feet on the ground while listening to the imaginative tales of his people. It is noteworthy to mention that the first Chicano works to receive international acclamation up through the 1970s were Bless Me, Ultima and El Teatro Campesino. During his career he was the recipient of some of the most prestigious awards, such as El Quinto Sol Literary Award, the American Book Award, the National Humanities Medal (presented by President Barack Obama), the NEA National Medal of the Arts Lifetime Honor (presented by President George W. Bush), and twice for the New Mexican Governor's Public Service Award, and many others.

Rudy Anaya was a man of simple tastes (red chile enchiladas at Barelas Café in Albuquerque) with profound convictions about Chicanos/as' potential. As a gifted storyteller, he masterfully created stories and characters, oftentimes with shamanistic and poetic qualities, that represent the struggle between opposite cosmic forces, usually ending with an optimistic outlook toward self-realization. In fact, most of his works embody a search for wholeness, opportunity, justice and goodness, as Ultima told Antonio. His writings inspire because they express universal truths and values. Talking to Rudy was often a memorable event for he possessed oracle qualities for his wisdom, passion for writing, and legendary generosity in promoting young writers. I loved calling him at his home because his answering machine seemed to share his humor by saying: "Can't answer the phone right now because I'm busy writing stories...". Rudy liked a good laugh con picardía, always promoting books, education and reading like an exemplary pied piper. He was a consummate conversationalist, a friend with a long memory, a gentleman. Only his humility was overshadowed by his greatness. He has now forever returned to the realm of his imagination, the world he sought in life to capture glimpses of owls, golden carps, black stones, subterranean lakes, blue guitars and La Llorona. Rudy has left us but he will be with us por y para siempre. Que en paz descanse nuestro amigo, hermano, maestro, Rudolfo A. Anaya. 


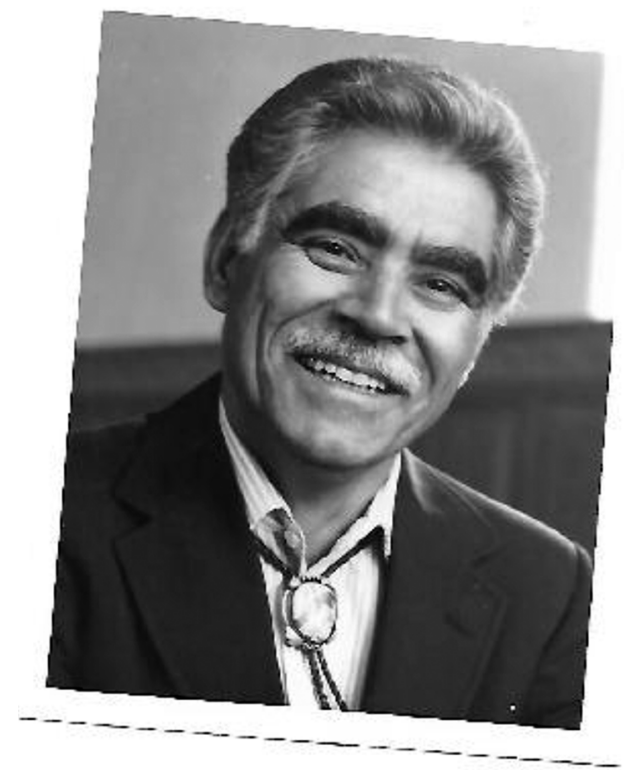

\section{BIOGRAPHY ON RUDOLFO A. ANAYA}

Rudolfo A. Anaya was deeply proud of being from Santa Rosa, New Mexico where the llanos reign in the dry eastern part of the state. With his iconic novel Bless Me Ultima (1972) set in that environment, he quickly gained notoriety, prompting a series of accolades as the godfather of Chicano literature. Others considered him one of the founders of the Chicano literary canon, while still others acknowledged that his work set the stage for an unprecedented acceptance of Chicano stories by the American mainstream. His realistic depiction of characters from the countryside or urban barrios along with magical real elements opened up new possibilities for understanding a long-standing Hispanic culture that had either been exoticized or ignored. He went on to produce a long list of memorable works of fiction, some nonfiction, along with plays, children's literature, essays, co-editions and poetry. He also mentored many emerging writers and his counsel and example became legendary.

He received all his education within New Mexico, the first years in the llano primary school and later high school and college in the city of Albuquerque. $\mathrm{He}$ graduated from the University of New Mexico with a BA in English and American Literature in 1963 and taught in the Albuquerque public schools until 1968. That same year he received his first MA in 1968 for English and his second MA in 1972 for Guidance and Counseling). In 1974, he was hired by the English Department at his alma mater and he taught there (mainly creative writing) until his retirement in 1995.

His common roots are attributed to his vaquero father and a mother whose family was devoted to farming. That grounded him well to appreciate the land, the 
landscape and the rhythms of nature within New Mexico, including archetypal characters, time, death and other features of life. He also experienced the urban barrio at a young age, while witnessing social issues of railroad laborers and the trappings of urban temptations. Much of his writings contain autobiographical allusions that serve as the surface to unearth profound feelings about existence, a philosophy of life (in particular the mixing of Hispano-Indigenous elements), dynamics of power vs powerlessness and the politics of being from a deep-seated but minority culture. From such representations, Anaya garnered a widespread following world-wide because he presented every-day people and folklore along with larger life questions that need to be resolved. In the process, he often proposed or insinuated a philosophy of seeking harmony and balance-along with hints of social justice-despite the coming together of opposites. Essentially, Anaya will be remembered for being a unique storyteller where imagination dictates the substance of humanity.

Anaya was a tireless creator through not only his own writings but also for sponsoring journals, serving as a consultant for films, and assisting with plays and operas of his works. He is truly one of the contemporary giants who has helped in gaining a legitimacy for Chicano literature across the globe. 